Click www.researchjournal.co.in/online/subdetail.html to purchase.

Volume 5 | Issue 2 | September, 2014 | 314-316 a e ISSN-2231-6434 |

International Research Journal of Agricultural Economics and Statistics

Visit Us - www.researchjournal.co.in DOI : 10.15740/HAS/IRJAES/5.2/314-316

\title{
A Case Study Efficacy of small area estimation against large area estimation-A case of wheat crop production
}

\section{NAJEER AHMAD D.G. AND VINAYAK N. JALIKATTI}

See end of the paper for authors' affiliations

Correspondence to :

VINAYAK N. JALIKATTI

Department of Agri

Business Management,

University of Agricultural

Sciences, DHARWAD

(KARNATAKA) INDIA

Paper History :

Received : 12.03 .2014 ;

Accepted : 28.08 .2014
ABSTRACT : Small areas estimation methods deals with the techniques for generating estimate for "small" areas based on the estimates produced for "larger" areas where the sample size is large enough to get precise estimates. The present study aims to know the efficacy of small area estimation (SAE) over large area estimation (LAE) in wheat production at Dharwad and Bagalkot districts of North Karnataka. The study revealed that the estimates based on $\mathrm{Y}_{\mathrm{q}}^{(\mathrm{l})}$ were less precise than that of $\mathrm{Y}_{\mathrm{q}}$ as a $>1$. However, the estimates based on $\mathrm{Y}_{\mathrm{q}}{ }^{(\mathrm{l})}$ and $\mathrm{Y}_{\mathrm{q}}{ }_{\mathrm{q}}^{(\mathrm{l})}$ were found to be very closed to wheat yield estimates as compared to that of $\mathrm{Y}_{\mathrm{q}}$.

KEY WORDS : Small area estimation, Large area estimation, wheat crop production

HOW TO CITE THIS PAPER : Ahmad D.G., Najeer and Jalikatti, Vinayak N. (2014). Efficacy of small area estimation against large area estimation-A case of wheat crop production. Internat. Res. J. Agric. Eco. \& Stat., 5 (2) : 314-316. 